$$
\begin{aligned}
& \text { SD } 143 \\
& \text { D } 4
\end{aligned}
$$





\title{
SOIL SURVEYS-FORESTRY
}

\author{
SPEECHES
}

OF

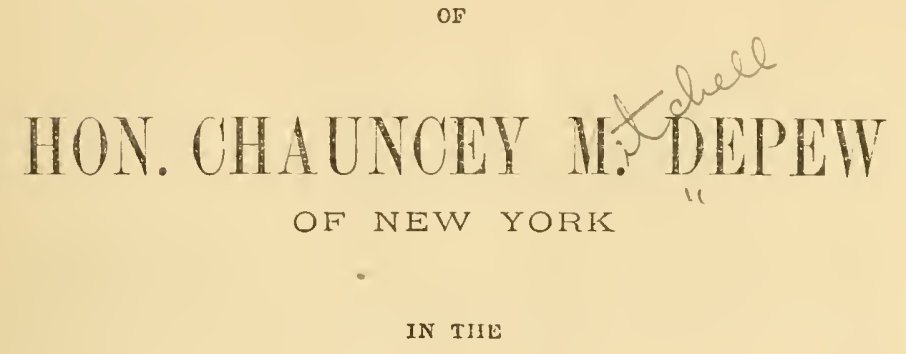

SENATE OF THE UNITED STATES

MAY 7 AND APRIL 30, 1903

䊁

WASHINGTON

1908

42170-7749

Fout print. off. 
UN? iyus
D. ot a.

$\therefore \vdots$ 


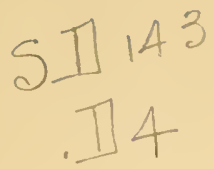

S P E E C H E

OF

\section{IION. CIIAUNCEY M. DEPEW. \\ FORESTRY. \\ May $\%, 1908$.}

The Senate, as in Committee of the. Whole, having under consideration the bill (II. I. 1915s) making appropriations for the Department of Agriculture for the fiscal year cnding Jane $30,1909-$

Mr. DEPEIT said:

Mi. President: I listened with great interest to the remarks of the eloquent Senator from Idaho when this bill was last maler discussion. Ire illuminates every subject which he touches, but some of us are compelled to differ with him npon his premises, his facts, and his conclusions. If we were back at the time when the country"was all forests and wilderness and there were few settlements, his argmment wonld be most impressire, but eren under such conditions the flaw in it is that as scientific forestry is now understood and practiced the carly settlens, instead of sweeping off the woods with reckless haste and waste, would have preserved a portion of them for the benefit of themselves and their posterity, both in wood supply and for water.

There are few subjects upon which the American people are so keenly alire as this one of forestry. I do not believe there is any branch of the Gorermment where the appropriation commands more general approbation. The forests on the public domain are an estate belonging to the whole people of the United States. The cost of their houses and food largely depends in the future upon scientific forestry. It has been our habit always to get all possible ont of the present withont reckoning the future. We nearly killed off our same and exterminated our song birds and insect-destroying birds for sport before we became alive to the necessity of their preservation.

We had reduced the fish in our rivers to a point where this food was no longer avalable at prices which brought it within reach of the people before we adopted a system of fish hatcheries. In some of the rivers when shad was thus propagated the fishermen, who thought the price might be reduced by an $42170-7749$ 
abundance of fish, attempted to assassinate the commissioner's of the state. Within our recent memory we have been depleting the forests of the country. It las been done by the most wasteful methods. The business has made some of the largest of multimiblionaire fortunes. Now, in the older States, tree planting is considered as necessary for agriculture or for profit as tree cutting in the olden tine was essential for the clearings.

The State of New York has within the last few years spent nearly two millions of dollars in purchasing what remained of primeral forests in the Adirondack region. They were being so lapidly depleted by masteful lumbering that the effect was already disastrous upon the navigation of the rivers, water for the canals, irrigation of the farms, and the prevention of floods. It was only day before yesterlay that a shipment of a million trees arrived in New Fork City from Germany in this movement to reforest the Adirondack region.

We have in the United States now a supnly of timber suflicient only for dhe next thirty years. When we consider the ecommical uses of wood this is alpulling. It will be a serious blow to the poor mon seeking to secure a home and inderiendence when his material must be either steel, brick, or concrete. The cost then becomes prohibitive. Already hard wood for furniture and domestic purposes has so risen in price as to prove a serious tax upon the homes of the American people. Every tiee that is eut down for ties for the railroad requires two growing ones to replace it, and forests are cut from year to year to supply the tremendous demands of our 200,000 mites of railroads. Every one of our sreat dailies cxhaust in a short time 10 acres of spruce cut for wood pulp. There is no doubt that if our forests were thrown open as leretofore a few great lumber comranies would make enormous fortumes, but at an expense to tho whole people of the United States in generations to eome which would be a thousandfold more than the fortunes thus accumulated in one generation to be dissipated in another.

Mr. Cleveland, who did many things in his $\Lambda$ dministration for which he will receive the praise of posterity, commenced the policy of forest reseries. IIe placed under the protec$42170-77+9$ 
tion of the Government about 20,000,000 acres, but for seroral years there was no policy of administration for the forests. On the contrars, they were practically locked up. This left them subject to forest fires and timber thieves. Tnpopularity of this isolation of a product of public necessity led whole communities to condone the stealing of the wood. In $189 \mathrm{~s} \mathrm{Mr}$. Gifford Pinchot was asked to take the head of a Bureatu of Forestry. He was at that time the only thorongly erlueated and experienced forester in the United States. Ther' were only two other's besides himself who had erer giren attention or study to the business. He mas, happily, so situated as to independence that he could lay aside careers which were open to him in the professional and business world, where large accumulations might have been had, to devote his time, talents, and experience to the public service. This he has done for ten sears with astouishing and most beneficent results. When he took up the work the United States had but. $40,000,000$ acres of this locked-up and unaministered forests. Now there are one hundred and fifty millions, but so managed that the public of the whole country are deriving inestimable benefits from their preservation and use. Mr. Pinchot, as a profound student of this question, had not only learned methods and results in older comntries, but experimented practically upon the estate of, a gentleman who was deeply interested in the preserration of the roods.

It is an illuminating experience for an American to travel over the continent of Europe and to see the care and scientific skill with which governments there look after the woods. I know of communities in Germany where the forests, owned in common by the municipality, pay the entire taxes by their annual yield under a system by which they are kept unimpaired. Happily for Switzerland, the early inhabitants, over a thousand jears ago, saw the effects upon theil hillsides and valleys of the destruction of the forests. After visiting deforested mountain sides and devasted valleys in the United States, it is a liberal education to see the Swiss mountains cultivated up to the snow line, the farm houses perched so high that they look like fairy cabins in the air, and the trees so growing as to $42170-i 749$ 
catch and hold the rainfall and the water from the melting snow. Except for this intelligent care Switzerland would today be minhabitable, these farms would long ago have disappeared from the mountain sides, the valley farms would hare been destroyed by torrents, and the streams rendered useless by the uneven fall of the water. There is almost as much care in Switzerland, Germany, and France of the tree as there is of a human being to prevent injury or to punish injury.

These countries not only keep their forests up to a full state of efficiency and replacement, but they derive an income of from $\$ 3$ to $\$ 5$ an acre from them. There was more wastefulness of the forest in France than in any other of the European comntries; but in repairing this France has been spending about $\$ 50,000,009$ in reforestation. During the last year the floods destroyed in some departments of France twenty-five to thirty millions of property and ruined thousands of families. The French have found that this was wholly due to cutting the trees from the hillsides, and it has led to an enormous increase of efforts for reforestation.

I had occasion at one time to stuly the Appalachian situation in our own comtry, and I came to the conclusion that with the deforesting of the Appalachian Mountains, which has already taken place, there has been a loss along the rivers which find their sources in these hills of more than $\$ 20,000,000$. a year.

Mr. BRANDEGEE. Mr. President-

The VICE-PRESIDENT. Does the Senator from New York yield to the Senator from Connecticut?

Mr. DEPEW. Certainly.

Mr. BR.ANDEGEE. Let me suggest to the Senator that not only are floods caused by deforestation, but the floods are succeeded by dronghts, which destros the narigability of the streams.

Mr. DEPEW. That is absolutely true. The droughts not only destroy the mavigability of the streams, but the streams are filled up.

One of the greatest triumphs, in my judgment, of Mr. Pinchot and of his able assistants has been that he has captured the $42170-77 \pm 0$ 
intelligent lumbermen of the country. The lumbermen of the comtry see alrealy the necessity of the work he is doing. I think it was at the last meeting of the Lumber $\Lambda$ ssociation of the United States that they passed resolutions to endow a chair of forestry in one or more of the unirersities of the cotmtry. of course there are sone great interests that are still opposed to this forest-reserve policy-and those great interests are sustained by honest, well-meaning, and intelligent people-

Mr. CLARK of Tyoming. Mr. President-

The VICE-PREsIDExT. Does the Senator from New York yield to the Senator from liyoming?

Mr. DEPEW. Certaiuly.

Mr. CLARK of Wyoming. I dislike to interrupt the Senator-

Mr. DEPEIV. It is all right.

Mr. CLARK of Wyoming. But for my personal information I should like to be adrised as to what the great interests atre and of whom they are composed that are opposing the forest policy?

Mr. DEFEIV. I understand that many of the great sheep interests are opposed to the forest policy, and I understand that many of the cattle raisers are opposed to the forest policy, and I understand that many lumber companies-and they have come into these forests in spite of ererybody and everything - are opposed to the forestry policy.

Mr. CLARK of Wyoming. The Senator, howerer, would not attempt to specialize as to what lumber interests are in favor of the policy and what lumber interests are opposing it?

Mr. DEPEW. No; I would not do that; but I know human nature and how it works, and I know how it has worked in the past. I call the Senator's attention especially to how the lumber interests have worked when they have had their own sweet will, unrestricted by the Gorernment or by anything but their own judgment, in Wisconsin, in Minnesota, and in Michigan.

Mr. CLAIR of Wyoming. I would ask the Senator whether or not he is informed that the largest private lumber interests in the world, the Weyerhauser interests, are in favor of the exact policy which the Forest Reserve Service is now carrying on?

$42170-7742$ 
Mr. DEPEW. Fecause they have been converted.

Mr. CLARK of Wyoming. After having acquired, substantially, all of the lumber in the United States save that which is owned by the Gorernment.

Mr. DEPEW. Mr. Weyerlrauser has got enougli. He knows that if the Goremment should yield what it has, he would get that; but he does not want nor think it wise to have it all in prirate ownership.

Mr. FLINT. Mr. President-

The YICE-PIESIDENT. Does the Senator from New York yicld to the Senator from California?

Mr. DEPETy. Certainly.

Mr. FLIN'T. I would suggest to the Senator from Wyoming that if the forest reserves had not been created the timber that has now been preserved and is in the forest reserves would be in Mr. Meyerhauser's possession, and he would have control of erery bit of the timber in the United States.

Mr. CLAliK of Wyoming. I am afraid the Senator from California misappreltended my position. I want to assure him that $I$ am in favor of forest reserves and not against them.

Mr. FLINT. I understand that.

Mr. DEPEW. Mr. President, under the administration of Mr. Pinchot the work of forestry has been carried to the woods, where it ought to be done. It is no longer mere bureau work of secretaries and bookkepers. In 1900 we had about eleven foresters in this country who understood the business, and in 1005 we have more than trelve hundred. All European conntries have schools of forestry, where young men are educated to enter upon forest care, both for the public and for private individuals as a career. One of the greatest successes of Mr. Finchot is that he has convinced the lumbermen themselves how unwise it is to destroy in a few years this source of perennial wealth. There is no greater reproduction in actual life of the fable of the goose that laid the golden egg than the cutting of of the forests. The lumbermen now understand that, and at their annual meeting they decided to endow chairs of forestry in some of the universities. Under the system pur$42170-7719$ 
sued up to the present time the waste ras incalculable and irreparable. That lumberman made the most money-and making money was all that was desired-who could best select the trees which would pay the best and conld be most rapidy and cheaply cut down and conveyed to the sawmill or the market. Each sear saw tens of thonsands of acres rendered worthless for all farming or agricultural puryoses forever.

But they saw more than that. These rast fields were the storage reseivoirs of the rains which held the floods and distributed the water during the dry seasons so that the streams were kept up, navigation was secured, and farms conld be irrigated. But with the wools taken off, the humus gathered there for centuries acting as a sponge to bold the water, the soil was swept into the streams and down upon the bottom lands, and then at the seasons of the melting snow or the big rainfalls the torrents did inealculable damage to vast regions of country.

Te do not have to theorize or romance in order to establish the disastrous results of onr former practice of lumbering. Corporations and individuals were rorking at their own free will and without any Gorernment supervision or control. Fifty years ago the white pine forests around the Great Lakes stretched continuously across the northern part of the States of Michigan, Wisconsin, and Minnesota. They were the greatest aggregation in one body of this valuable wood in the world.

To-day white pine has become so searce and expensire as to be almost inaccessible to the ordinary purchaser. In these forests a half century ago was the almost incaleulable amount of 350 ,000,000,000 feet, board mensure. The great lumber companies rushed in, each striring to outdo the other in the harvest of the rools. They eut at the rate of nearly $\$, 000,000,000$ feet, board measure, a year. They reduced the price by competition so that it paid only to take the best trees. The cuttings and the slashings and the slabs were left and became fuel for forest fires. These fires, fanned by the fierce winds of the North, burned orer the areas from which the wood had been ent and into the roodis themselves. They burned up the rieh soil which hat aecumulated for centuries and left only the sand underncath. Then came the flools which washed these sands into the rivers, so $42170-i 7+9$ 
that many of the streams of the Northwest which were formerly narigable are now useless. Not only was it made impossible for these woods to grow again, but the whole region becane an arid and uninhabitable waste.

The statement has been made that forests cut down this waly will easily reproduce themselves without assistance or care, but it takes eighty years for a white-pine tree to reach maturity nhere it can be profitably cut. The lumbermen, in sweeping off the trees that were marketable and burning the rest, destroyed the nossibility of a new growth, aud the same would happen if our present forests were thrown open to this destructive competition. We must remember all the while that this destrucion is upon the public domain belonging to the people of the United States, and of the property which should be for all time a source of protection and revenue to the people of the United States.

With all the figures that were presented here in regard to Idaho being deprired of her population in the future because of forest reserves within her borders, if I have calculated correctly from the figures giren-I have not had an opportunity to examine them since-there is only 5 per cent of Idaho in forest reserves. But under the intelligent supervision and under the intelligent care of the foresters to-day we accomplish many things. They are running roads through the forests, to which they objected. They are extending telegraph and telephone lines through the farests, which were objected to.

Mr. BORAII. Mr. President-

The VICE-PRESIDENT. Does the Senator from New York yield to the Senator from Idaho?

Mr. DEPEW. Certainly.

Mr. BORAII. I simply wish to ask if the semator stated that the forest reserves in Idaho are only 5 per cent:

Mr. DEPEW. That is the figure I have arrived at from the statistics presented. Is it more?

Mr. BORAIr. I think it is 30 per cent.

Mr. DEPEIr. It is my mistake. I made the mental calculatron as the Senator"s colleague spoke yestertay. They are running telegraph and telephone lines through these forests, with $42170-7749$ 
the result that there is free communication in the forests, with the result that the homesteader can go through the forests, and the wood can be got out.

It is said the homesteader is deprived of his claim. But under the law passed two sears ago any land within the forest area which is fit for homesteacling ean be located the same as it could erer have been before.

Mr. CLARK of Wroming. I will ask the Senator if he is informed of the fact that the proclamations creating the forest reserves since that time have especially marned every person from making settlement therein?

Mr. DEPEW. I do not know what proclamations have been issued. But the law has not been repealed, and every homesteader has his right under the law, and any proclamation which is in violation of the law is iuralid; and I do not think such a proclamation would stand for an instant.

Mr. SMOOT. Mr. Piesident

The riCE-PRESIDENT. Does the Senator from New York yield to the Senator from Ctah?

Mr. DEPEIV. Certainly.

Mr. SMIOOT. For the information of the Senator from Wyoming I will state that no matter whether proclamations have been issued or not, the lieople are now going into the forest rescres and making homestead entries there, and within the last few months orer a thousind have been made in the forest reserves in this country.

Mr. DEPLW. There is another way in which the homesteader is protected. He has a home on the outside of the forest reserve, and nuder the administration of this great Department he can get wood free out of the forest for his honse and his fences and his domestic purposes, while if the lands rere in private hands, he would be feuced out and he would have no such privileges.

In the course of the debate on this question at rarions times there has been much said about these roods being elenred to furnish homes, but our experience has been that the methods we have adopted for the clearing of the roods have destroyed thousands upon thousands of homes already in existence and $42170-7749$ 
left no region within what was the woods which could be utilized for homes.

Asia in ancient times supported myriads of people in countries which are now practically arid deserts: Modern scientists have demonstrated that this rast destruction of the productive power of the earth to sustain human beings has been the result of the waste of the wouds.

Our forestry system, under Mr. Pinchot and his assistants, has gone far enough to demonstrate that the woods instead of being destroyed in thirty year's can last productively forerer for the people of the United States. With a sufficient number of trained foresters, with pathways and roadways, with telephone and telegraph lines for communication, and with proper apparatus, fires are reduced to a minimum and loss from that cause is practically eliminated. An intelligent cutting of selected trees and conservation of growing ones keeps the forests for all time in healthy and productive conditions. We are exhausting the wealth with which nature has so richly endored us at a terrific pace. It is estimated that in a hundred years our coal will be gone; that within fifty years our iron ore will be exhausted, and our other minerals will be used up with equal rapidity.

But the forest is never exhausted. It replenishes itself. It is a perpetual source of rerenue, safety, health, and income, and gives to the people of the country comfort and wealth, without cost to the National Treasury. Experience and criticism have done away with erery complaint which can be legitimately laid against forest reserves. Instead of the land being taken out of public use, it is preserved for the public use. Instead of grazing upon the public domain being a privilege of the strongest and the most unscrupulous, it is now under the supervision and operation of the Bureau of Forestry, brought within the reach of erery citizen who chooses to avail himself of the opportunity. Of course cattlemen of great resources, who, few in numbers, hare rirtually captured the whole grazing country belonging to the United States, make ceaseless war upon this opening to every citizen of his opportunity. Of couse the more unscrupulous of the lumbermen, who would combine and seize mpon and then destroy the forests, are opposed to the $42170-7749$ 


\section{3}

system of preservation, conservation, aud sale of the timber, witliout farors to any.

The home seeker can not complain, because if there is any part of the forests fit for him he can locate his farm. If he has laid out his home upon the borders of the forest, it is not the property of a gigantic lumber company which fenecs him ont, but under the rules of the Intreau of Forestry he is permitted to take the trees that are necescary for his fences or his house and also the ground for the nasture of his stcek. Citizens secking health or sport find that they are no longer fenced ont or driven out, but that the rools belonging to the Government, and, therefore, to the people, are open to them, and that the protection granted by the methods carried out by the fire wirlens protect them from that danger. It has been said that the United States has no right to go into the lumber or grazing ol cattle or sheep or goat business, but the United States has the right, instead of letting a few individuals or corporations have the public domain for nothing, to grant the privilese to all the people who desire to take adrantage of it of entering upon the lumber or cattle or stock business within the puldie domain, upon such terms that the people of the comntry shall not be taxed to pay for the privileges which these few citizens enjoy. Those who make money by using these forests should contribute a portion of the cost of their administration and preservation.

The administration of the forestry division of the Government compares farorably not only with every other department, but with any private business in the country. The forestry atministiation in 1890 was without rerenue to the Goremment, but in 1901 the Bureau had been practically organized. Then the cost of administration was $\$ 325,000$ and the receipts $\$ 206,000$. In 1907 there was a profit of about $\$ 150,000$, and in 1nos the area of the forest reserves had risen from about $40,000,000$ to $150,000,000$ acres. The cost of administration was, in round numbers, $\$ 3,400,000$. If we take ont of that the permanent improvements and the forestry iurestigation, which is also a permanent improrement, the cost of the administration was only $\$ 1,450,000$ and the receipts $\$ 2,000,000$.

To show how the people of the United States, without farorit$42170-7749$ 
ism, are enjoying the privileges of grazing within these forests, and for which a small charge is made per head, the number of cattle in 1901 was, in round numbers, 278,000 , and in 1907 , $1,200,000$; of sheep and goats in 1901, 1,211,000, and in 1907, $6,660,000$.

The Govermment received for these grazing privileges in 1906 $\$ 515,000$, and in $1907, \$ \$ 01,000$. The timber sold in board feet in 1904 was $113,000,000$, and in $190 \pi 1,045,000,000$. The receipts from sales of timber was, in 1904, $\$ 5.000$, and in 1907 , $\$ 657,000$.

Mr. rresident, I submit as an irrefutable proposition that no other Department of the Government can show results like these. Our one hundred and sixty millions for pensions is a delot of gratitule to the men who fought to save the Union and those dependent ujon them. Our two hundred millions a year for the Arny and Nary are for the pulblic defense in case of war. Our hundreds of thousands for the diplomatic and consular service are for peace and commerce. Our taxation throngh the tariff and the internal revenue are to pay this vast delst of gratitude and the annual expense of maintaining our position as a world power. We spend eighty millions nearly every year for rivers and harbors, and forty of that is thrown away because the streams are filled up again from the floods following the deforestation of the lands.

But here is a Bureau which preserves the streams for navigation and irrigation, preserves the mountain sides and the ralleys with their productive possibilities for the farmer, preserves the timber for the manifold uses which are the necessities of the American people, and keeps bown the price of the lumber so that it will remain within the economical reach of our citizens. At the same time it is carried on with such skill, effciency, and integrity that, while thus freserving and enriching the nation, its administration is rithout cost to the Government, but, on the contrary, an annual profit is paid into the Treasury.

Sir, I trust that the amendment of the Senator from Idaho, prohibiting the transportation of wood out of any State, will be yoted down, and that this appropriation, paid for already withol:t taxation and without cost, will he parsed as it came in the recommendation from the secretary of Agriculture.

$42170-7799$ 
SOIL SUPVEYS.

April 30, 1908.

Mr. DEPEW. Mr. Iresident, I dislike always in any way to disagree with the conclusions reached by a committee, and would not in this case have said anything if there had not been such a radieal change in the bill as it passed the Ilonse.

The Senator from Wyoming [Mr. ManRen] asks us where onr information eomes from, and if by any possibility it ma be better than that which the committee receired. My information comes from agricultural societies and granges in the State of New York. I have a letter here from a distinguished agrieulturist inclosing a speech mate by one of the members of the New York delegation during the debate when this subjeet was mp before the House of Representatives.

It seems to me that the only question at issue is the time which will be involved in the performance of this work. Everybody admits the necessity for the work and its enormous valne. The question is, shail it be done rapidly or shall it be spread over a longer period, and that depends upon the amount of the alpropriation.

The information which I have received from these people who are so deeply interested and who have consulted with the Buren of Soils is that the difference in this appropriation as it passed the Ifonse and is cut down by the Senate committee makes just double the time required to perform the work alrendy mapped out.

This Bureau has done valuable service to the agricultural interests of the State of New York. The surveys which it has made in the counties along the Lake region in regard to grape enlture have enriched that industry in that part of the State. They are now engaged in two kinds of mork mhich interest greatly the farmers of New Fork, one in relation to the abandoned farms in the Southern tier and the otliel the cultiration of alfalfa for the dairy interests.

One would hardly smppose that there were abandoned farms in the State of New York, but it is a fact that in some of the counties in the southern tier the soil Las become exhansted. $42170-7740$ 
The people of the locality can not, by their own efforts, carry on the iurestigations which are necessary to make those farms sufficiently productive for profit or even for a living. The result is that farms are abandoned. The work which has already been done in a limited way ly the Bureau of Soils survey has brought many of those farms into production again, and the whole of that section is looking with the liveliest interest to an immediate and energetic contiuuation of the work because of the results following what the Bureau has already done.

The dairy interests of New York are among the largest in the United States, and those interests have been suffering by the exlaustion of dairy soil and are alive to the necessity of finding fresh materials for feeding stock. It has been found that this necessity is abundantly supplied by alfalfa if the soil can be located which will economically and profitably produce it. That has been discovered in a great district, nearly 400 miles in length, between Albauy and the Lakes.

Now, constituents of mine who are interested persomally, and public-spirited citizens whose studies are in the line of agriculture, feel that unless this aduitional apropriation is made the work both of rectaiming farms and producing alfalfa will be delayed, to the infinite divarlvantage of the agricultural interests of the State of New Yorl.

We find that the committee of the IIonse appropriated, on the information which they had, $\$ 100,009$. THen, in the debate, on information received from luactical farmers on the floor of the Inouse, the amount was raised there to sos.soco. Now, the senate committee, on further testimony, las reluced it $10 \$ 200,000$.

So the whole discussion, from its origin in the IIonse committee mutil its arrival on the flowr here, demonstrates that it is a flud question, to be determine by the information we can derive from any soure where that information can be procured.

Under the circumstances, Mir. l'resident, I am compelled, much as I regret it, to differ from the conclusions of the committee and to rote for the restoration of the amount passed by the House of remresentatives.

$42170-7749$ 



\section{LIBRARY OF CONGRESS}

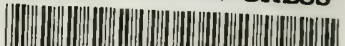

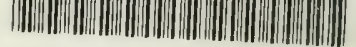

0000921 5384 